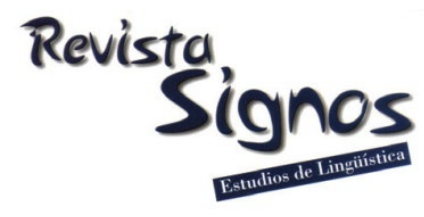

\title{
The agreement letter: Linguistics as a hermeneutic tool in professional discourse
}

\author{
La carta acuerdo: La lingüistica como herramienta hermenéutica \\ en el discurso profesional
}

Guiomar Elena Ciapuscio

UNIVERSIDAD DE BuENos AIRES

CONICET

ARGENTINA

gciapusc@gmail.com

Recibido: 24-VI-2021 / Aceptado: 08-IX-2021

DOI: $10.4067 /$ S0718-09342021000300736

\begin{abstract}
This paper stems from the conviction that Linguistics should not be limited to description and theorisation efforts, but also assume a more active and committed role in improving the exchanges that take place in the field of specialised or professional communication. The purpose of this article is twofold: to describe and characterize a prospective professional genre, the business agreement letter, and to provide specific knowledge about the linguistic expertise process on the basis of a relevant experience. From the Text Linguistics point of view (Schröder, 1991; Ciapuscio, 2003, 2016; Adamzik, 2004, 2016), and also taking into account the lexical-grammatical analysis, this article provides a generic description of the business agreement letter, with the aim of describing expectations and protecting the signatory parties from events that may take place in the future, which frequently result in interpretive problems. The case under analysis corresponds to an extensive legal and commercial controversy that arose in Argentina, as a result of a share purchase-sale contract, which required the collaboration of a linguistic expert. In this sense, it provides general knowledge about the linguistic expertise process and evidence on the relevance of linguistic advice services during the production and interpretation of professional texts.
\end{abstract}

Key Words: Professional genres, business agreement letter, forensic linguistics, ambiguity, text interpretation. 


\section{Resumen}

Este trabajo parte de la convicción de que la lingüística no debe limitarse a describir y teorizar, sino que tiene que asumir un papel más activo y comprometido en la optimización de los intercambios que ocurren en el marco de la comunicación especializada o profesional. El artículo se propone alcanzar un doble propósito: describir y caracterizar un género profesional prospectivo - la carta acuerdo comercial - y aportar conocimiento específico acerca del proceso de peritaje lingüístico, a partir de una experiencia significativa. Desde la perspectiva de la lingüística del texto (Schröder 1991; Ciapuscio, 2003, 2016; Adamzik, 2004, 2016) y con el auxilio del análisis léxicogramatical, se ofrece una caracterización genérica de la carta-acuerdo comercial, cuya finalidad es describir expectativas y proteger a las partes firmantes de hechos que podrían ocurrir en el futuro, y que frecuentemente dan lugar a conflictos de interpretación. El caso estudiado corresponde a una extensa controversia legal y comercial suscitada en Argentina, a raíz de un contrato de compra-venta de acciones, que demandó la colaboración de una perita lingüística. En este sentido, el artículo aporta conocimiento general sobre el proceso de peritaje lingüístico y provee evidencia sobre la relevancia del asesoramiento lingüístico en la producción e interpretación de textos profesionales.

Palabras Clave: Géneros profesionales, cartas de acuerdo comerciales, peritaje lingüístico, ambigüedad, interpretación textual.

\section{INTRODUCTION}

In the linguistic community, the idea that Linguistics should assume a more active and committed role in specialised or professional communication is broadly accepted, providing guidelines to improve or optimise public and institutional exchanges (at a company, state, university and citizenship level), both in the production as well as in the interpretation of texts (Cabré, 1999; Göpferich, 2000; Parodi 2005; Montolío, 2010a, 2010b; Bhatia, 2010, 2015; among many others). In the field of professional discourse, especially in the areas of legal and commercial communication, the potential contributions from this discipline have not been sufficiently recognized yet. For instance, Text Linguistics could contribute to Forensic Linguistics, a speciality that has been gaining more prestige and recognition during the last decades, Coulthard (2005) states that when forensic linguists are summoned to court, they usually have to answer two fundamental questions: What does a given text say? and Who is its author? This paper addresses the expert consultation linguistic expertise task when trying to answer the first question partially, based on a multi-dimensional text analysis of an agreement letter, an unexplored professional genre in the Spanish language.

Specialized discourse genres in Spanish have been more widely studied during the last two decades. However, the epistolary genre of scientific and specialized discourse is a relatively unexplored field (Ciapuscio \& López Ferrero, 2021); previous studies on professional letters are even more scarce: it is worth mentioning the works on job application letters (Díaz \& Lucha, 2018; da Cunha \& Montané, 2020) and those that focus on the letters of complaint (Pastor Villalba, 2011) from a Spanish-German 
contrastive perspective. There seem to be no other studies on the business agreement letter in Spanish yet.

Due to the characteristics of the expert consultation task itself -and the confidentiality requirements involved-, there appears to be little literature and empirical knowledge on the subject. Thus far, very few studies have been conducted on the nature of the task, corresponding procedures, and ways to address and solve interpretive problems, as well as on the genres used to discursively conduct such task. Similarly, there is not enough empirical knowledge on prospective professional genres, such as letters of agreement. These documents are of great importance for the resolution of commercial disputes, as they are intended to describe each party's expectations and protect them from events that may take place in the future. In short, the interpretation of such texts could impose economic and legal benefits or damages to the parties. Therefore, beyond a purely theoretical interest, linguistic research on this particular genre is highly relevant for its practical implementation.

This article presents the linguistic expertise process and focuses on this genre, which has the fundamental purpose of establishing what, in the field of law, is called 'condition' (that is, the subordination of existence or extinction of an obligation to a future and unknown event). In order to achieve these objectives, firstly, the theoretical and methodological framework of the study is introduced; secondly, an overview of the linguistic expertise process and the tasks performed; thirdly, I present the superstructural and macrostructural analysis of the letter of agreement and some morphosyntactic and lexical aspects, particularly relevant to understand the interpretation that tried to provide a grounded resolution for the dispute. Finally, I present a summary of the topic and discuss the implications of the results.

\section{Theoretical and methodological framework}

This article is developed within the general theoretical framework of Text Linguistics, following the Germanic tradition (Heinemann, 2000; Heinemann \& Heinemann, 2002; Adamzik, 2004, 2016). From this perspective, claims have been made about the close connection between Text Linguistics and Text Hermeneutics, one of its primary antecedents, especially since the cognitive aspect and the role of interpreters when assigning sense became the main interest (Adamzik, 2016). The 'text' unit is conceived from a double perspective: as a physical object ('superficial text') and as a mental phenomenon ('text in our mind'), which is described in Hermeneutics as the 'fact from thought' or 'fact from spirit' (Adamzik, 2016). Regarding the specialised discourse, this article is written under the tradition of specialised Text Linguistics (also called 'specialised communication', Schröder, 1991). Scientific and professional texts are considered multi-dimensional objects (Ciapuscio, 2003; Parodi, 2005), whose different components (functional, situational, semantic and linguistic ones) are deeply and dynamically interrelated with the extra-linguistic context where they stem from, which 
also gives them sense (Ciapuscio, Adelstein \& Gallardo, 2010; Ciapuscio, 2016). Specialised discourse genres are part of the communicative tools of scientific and professional communities, and they avail the solution to social and individual tasks, taking specific roles in the tasks or subtasks in the field. For the current study, genres are conceived at two levels: on the one hand, an external structure that derives from the relation between their communicative action and the social structure on which they are based and, on the other hand, an internal structure that emerges from its basic function and its material-linguistic base (Bergmann \& Luckman, 1995; see also Sandig, 2000; Ciapuscio, 2021). In this sense, even though there are sensitive differences in emphasis and theoretical-analytical instrumentarium, the general vision converges in contemporary directions that study the professional communication in a comprehensive way, for instance, the critical genre analysis (Bhatia, 2015).

From the methodological point of view, the research assumes a qualitativeinterpretive approach. It consists on the analysis of an expert consultation task and an exhaustive study of the potential interpretations of a text, considering its intertextuality with extensive documentation on the case. For the analysis of the letter of agreement, the multidimensional approach (Adamzik, 2004; Ciapuscio et al., 2010) is used, which considers the text as a 'verbal Gestalt', that is, as a network of relationships between the different aspects of the different dimensions (functional, situational, thematic), which are part of multilateral relations of reciprocal conditioning that constitute their coherence. In the 'verbal Gestalt', different levels of textual conformation or organization are recognized, which result from the interaction of the dimensions in the verbal framework. These levels of linguistic conformation are: the actional structure of the text (illocutionary conformation); the rhetorical-stylistic structure (superstructural conformation); the macrostructures (semantic conformation); and the lexicalgrammatical conformation. The analytical effort carried out in this article seeks to describe the superstructural and macrostructural aspects and shed light on the lexicalgrammatical features that enabled the possibility of interpretive ambiguity and gave rise to the conflict of interests of the parties.

\section{The linguistic expertise process}

\subsection{The case}

The controversy leading to the linguistic expertise task took place in Argentina, as a result of a substantial change in the economic legislation, after a major socio-political and financial crisis. From March, 27th 1991 to January, 6 $6^{\text {th }}$ 2002, the country was regulated by what is known as the Convertibility Law $(23,928)$, which pegged the value of the Argentine peso (at that time, known as 'austral') to that of the US dollar; passing that law, the centre-right Peronist government intended to stabilise the economy and tackle inflation, which has been disrupting the country since the middle of the $20^{\text {th }}$ 
century. The dispute arose in March 2001, when even though the law was still in effect (the 1 ARS = 1 USD rate was guaranteed by the Central Bank of Argentina), indicators of a different type already predicted the possibility that the Argentine state could no longer sustain the convertibility system from peso to dollar. At the time, an important service company, property of a European firm, was sold to another conglomerate (mostly constituted by international enterprises). As a consequence of the unstable economic context in which the sale and purchase agreement took place, the parties negotiated the signing of a letter of agreement through which they tried to address the possibility of the Convertibility Law losing effect within a period of nine months, by December, 31st 2001, - which was finally the case, at least as far as the facts are concerned. The purpose of the letter of agreement was to define such eventuality or contingency: a change in the conditions between March, 31 st 2001 and December, 31st 2001; and, if appropriate, to settle a pricing adjustment for the operation. The parliamentary derogation of the Convertibility Law came into effect on January, $6^{\text {th }} 2002$ and the regulatory decree on January, 9th 2002; but, at least since December, $1^{\text {st }}$ 2001, several events took place - particularly, increasing restrictions for the withdrawal of dollar deposits from enterprises and individuals, which came to be known as the corralito, and the announcement of bank holidays, which meant that it would be impossible to withdraw money or perform banking operations-, provoking a conflict between the selling and buying parties. The parties confronted each other due to the possible interpretations of the letter of agreement. This dispute, which lasted several years and required the intervention of experts, solicitors, economists and linguists, was arbitrated and resolved by the International Court of Arbitration of the International Chamber of Commerce (CCI). The legal proceeding — which implied a significant amount of texts of different genres, such as contracts, statutes, lawsuits, counterclaims, experts' reports, court hearings, verdicts - was carried out and solved through the use of texts, and it could not have been solved in any other way (Antos, 1997). For this reason, one of the parties involved in the dispute deemed its linguistic dimension extremely relevant, as did the international court summoned to settle this conflict.

\subsection{The text of the dispute and the linguistic expertise process}

The linguistic expertise lasted three and a half years of continuous work. The claimant (selling party) asked for the expert opinion of a linguist, in order to construe the meaning of the word desvinculacion (de-linking) included in the second paragraph of the letter of agreement, quoted below: ${ }^{1}$

(1) Esta carta se refiere al Contrato de Compraventa de Acciones (el "Contrato") y a la carta referente al mismo firmados por las partes el 30 de marzo de 2001. 
1. Los firmantes acuerdan que el precio pagado por XXX, de acuerdo con lo establecido en la cláusula 2 del citado Contrato, será sometido a una revisión si se produce la Contingencia prevista en el párrafo segundo de esta carta hasta el 31 de diciembre del año 2001.

2. A los efectos de esta carta se entiende por Contingencia la desvinculación del tipo de cambio oficial del peso argentino con el dólar USA, cualquiera que sea la causa que la produzca.

3. En el supuesto de producirse la Contingencia establecida en el párrafo anterior, los vendedores reintegrarán a YYY en caso de disminución del tipo de cambio oficial del peso respecto al dólar, o YYY a los vendedores en caso de aumento del tipo de cambio oficial del peso respecto al dólar, una cantidad en dólares de Estados Unidos conforme al apartado 4 siguiente de esta carta.

4. La cantidad a que se refiere el apartado 3 anterior se calculará en la forma establecida en el Anexo a esta carta, teniendo en cuenta, en todo caso, que los precios base de la compraventa serán los establecidos en la cláusula 2 del Contrato. Como base para el cálculo, se tomará el promedio de la cotización oficial del peso argentino frente al dólar de Estados Unidos durante el período comprendido entre la fecha que se produzca la primera alteración de la paridad peso/dólar y el 31 de diciembre de 2001. Las cantidades resultantes se liquidarán, de producirse la contingencia y se pagarán sin intereses antes del 15 de enero de 2002.

5. En el supuesto de que se produzca algún pago de acuerdo con lo establecido en la presente carta, los valores que figuran en la tabla del Anexo a la carta de 30 de marzo de 2001 se incrementarán o reducirán para todos y cada uno de los tramos en el mismo porcentaje que lo haga el precio del Contrato.

Firmado el 31 de marzo de 2001 en tres ejemplares.

\section{EMPRESA 1 (compradora) EMPRESA 2 (vendedora)}

This letter refers to the stock sale and purchase agreement (the 'Contract') and the letter regarding the contract, both signed by the parties on March, 30th 2001.

1. The signatories agree that the price paid by XXX, in accordance with section number 2 of the Contract, will be subject to revision if the Contingency anticipated in the second paragraph of this letter takes place before December, 31 2001.

2. For the purposes of this letter, Contingency is understood as the desvinculacion of the official exchange rate of the Argentine peso with respect to the US dollar, regardless of the cause that produces it.

3. In the event of the Contingency determined in the previous paragraph, the sellers will reimburse to YYY an amount in US dollars, in accordance with paragraph 4 below in this letter, if the official exchange rate of the Argentine peso decreases with respect to the US dollar; or YYY will reimburse the sellers that amount if the official exchange rate of the Argentine peso increases with respect to the US dollar. 
4. The amount referred to in paragraph 3 above will be estimated according to the Annex to this letter, taking into account, in all the cases, that the base prices of the sale will be established in section 2 of the Contract. As a basis for the estimate, the official price averaged of the Argentine peso with respect to the US dollar during the period between the date of the first modification of the peso-dollar parity and December, 31 st $^{\text {s }} 2001$ will be considered. The resulting amounts will be settled, in the event of the contingency, and will be paid with no interests before January, $15^{\text {th }} 2002$.

5. If any payment is arranged in accordance to what is established in this letter, the values stated in the chart of the Annex to this letter dated March, 30 2001 will be increased or decreased for all the sections in the same percentage as the Contract price.

Signed on March, 31st 2001 in three copies.

COMPANY 1 (buying party)

COMPANY 2 (selling party)

The dispute between the parties focused on the interpretation of the word desvinculación, because the sense the judges gave to that nominalisation (a typical characteristic of specialised discourse and, particularly, legal discourse, cfr. for instance, Ruiz Moneva, 2013) would result in the obligation or lack of obligation of payment by the buying party, in order to compensate the selling party with a milliondollar sum. While the selling party advocated for a general interpretation of desvinculacion, the buying party insisted on making a restricted interpretation, as a synonym of the economic term devaluation, which would suit their interests. Consequently, the buying party would not have the obligation of disbursing a million-dollar sum because the legislative derogation of the fixed exchange rate had occurred, as anticipated, on January, 9th 2002, once the time limit established in the letter of agreement had expired.

Although the focal point was the nominalisation, performing a disambiguation naturally required the analysis of the complete letter as well as the consideration of the explicit references found in the text (the sale and purchase agreement and other accompanying texts), the texts prior to the signature (different memorandums of understanding), bank rules and regulations, specialised economic articles as well as general and specialised newspaper articles, among others. In other words, in order to interpret the letter of agreement it was necessary to examine the linguistic and discursive context of the controversy (the discursive universe in which it was produced) and its cultural socio-historical and political context. A description of the general expertise procedure, arranged in sequential order is provided below.

First stage:

- Immersion in the thematic domain and the specific problem

- Source analysis (internal documentation of the case and external documentation: specialised texts from the domain, specialised press texts, etc.)

- Lexicographical survey and analysis: general and specialised dictionaries to look for corpus of relevant lexemes for the dispute

- Consultation with experts (particularly, economists and solicitors) 
- Comprehensive linguistic analysis: morphosyntactic, lexical, textual and generic dimension levels

Second stage:

- Writing of partial expertise reports

- Revision and discussion of the results with other experts

- Comprehensive linguistic analysis, expansion and adjustment of previous results

- Restatement of partial expertise reports

- Production and writing of the linguistic expert opinion (along with legal and economic expert opinions, presented as part of the claim to the International Court)

Third stage:

- Oral presentation of the linguistic expert opinion before the International Court

- Defence of the linguistic expert opinion (interrogation by the Court and the counterparty experts)

- Expansion of the linguistic expert opinion (written responses to the Court's questions, after the defence)

As can be seen, the expertise required a variety of skills and proceedings: regarding the genres used in the process, both written (reports, opinions, extended legal opinion) and oral genres (consultations with experts, questions and discussions, oral presentations before the court, expertise defence) were relevant. The task of disambiguating the interpretation of professional texts implies not only a broad process that demands discipline-specific skills and different generic capabilities, but also the need of acquiring a sound knowledge of the problem intended to be solved in the dispute.

\subsection{The letter of agreement}

Letters of agreement are professional prospective texts, which are intended to establish limits or regulatory frameworks to future and/or hypothetical events. In these letters, the terms of an agreement between two or more parties are established by written procedure — so each of them accurately knows its responsibilities and protects its legal rights - and the issues involved in these texts can vary (confidentiality agreements, cohousing agreements, rental agreements, etc.). Letters of agreement help avoid future confusions or additional negotiations, as each of the contracting parties or commercial partners can refer to the document as needed.

\subsubsection{Functionality and global structures}

In the professional prescriptive literature, there is a certain fluctuation in the use of the terms 'letter of agreement' and 'contract'; They are often used synonymously, leading to the interpretation that they belong to the same genre. In any case, there is strong evidence that commercial contracts are usually coupled with letters of agreement, which constitute binding texts for the parties and have the purpose of shedding light 
on the interpretation of different aspects that might generate a conflict in contracts. In this sense, the fundamental function of the letter of agreement is directive and, more specifically, commissive, since the parties assume a commitment to comply with its provisions. This characteristic deepens its link to commercial contracts. However, (and unlike contracts) due to their prospective anticipatory nature toward unknown events, their production is usually deliberately general, resulting in the presence of ambiguity or vagueness.

Indeed, letters of agreement only show some features of the family of specialized epistolary genres (Ciapuscio \& López Ferrero, 2021). In the text under analysis, regarding the rhetorical scheme, the letter of agreement differs from other epistolary genres in that it lacks the prototypical heading and closing formulas. It also differs in the ways of interaction; thus, although they exhibit the dyadic nature, since two parties are making a commitment, there is no direct interaction between the interlocutors (an 'I' addressing a 'you', cf. for example, Barrenechea, 1990; Bouvet, 2006). The interlocutors are mentioned in the third person with nominal forms such as 'the parties', 'the signatories', 'the buying party' and 'the selling party' and, at the closing, by means of the signatures and the mentions of the names of the companies.

The following is a more detailed analysis of the global formal structure (superstructure) of the letter, which is the main focus of the analysis (1).

As can be observed, the letter of agreement consists of an introductory paragraph where the reference (and abidance) to the stock sale and purchase agreement, and to the accompanying letter is stated, along with the corresponding submission date. This section determines the reference setting of the text. The content of the letter is displayed along five correlated and numbered paragraphs, interlinked through a conditionalimplicative connection, similar to the imagery of Russian dolls as each layer leads to a more specific one, articulated in the previous layer. Namely, a logical and sequential general order corresponding to a superstructure with an argumentative base underlies the formal structure of the letter: each paragraph introduces the subsequent paragraph, with semantic connections in a predominantly conditional order ('if A, then B'); such conditional connections are also evident in the internal structure of some paragraphs. In this manner, the general interpretation of the letter of agreement obeys to a consistent logic in which, if the hypothetical events take place, the possible consequences are defined. Reciprocally, the materialisation of these consequences depends on the effectiveness or occurrence of the hypothetical events that generate them. The recurrence of conditional structures and connections is a characteristic of the legal discourse (see Montolío, 2010b) and it explains the prototypical complexity of its specific genres (Orts, 2015).

In order to exemplify the formal structure of the body text, here are the two first paragraphs: 
1. The signatories agree that the price paid by XXX, in accordance with section number 2 of the Contract, will be subject to revision if the Contingency anticipated in the second paragraph of this letter takes place before December, 31st 2001.

2. For the purposes of this letter, Contingency is understood as the desvinculación of the official exchange rate of the Argentine peso with respect to the US dollar, regardless of the cause that produces it.

In 1 . the possibility of adjusting the sale price established in the agreement before December, $31^{\text {st }} 2001$ is presented, in the event that the so called 'Contingency' occurs. This could be paraphrased with the following structure: if $C$ (contingency) occurs (before 12/31/01), 'then' $\mathrm{R}$ (revision of the price). As expected in the legal discourse (Beaugrande \& Dressler, 1997; Gotti, 2008; Bhatia, 2010), the crucial expression for the negotiation, 'contingency', must be defined in detail —an effort displayed in paragraph 2. Here, a stipulating definition is introduced (Copi, 1972), agreed on by the parties (after several hours of debate and consecutive drafts) which in turn is what finally led to the dispute and an international lawsuit: in other words, the choice of a general word, desvinculacion, which in this professional context may be qualified as vague, produced an interpretive battle between the parties, fought before the CCI since July, 2002.

\section{Continuing to paragraph 3 :}

3. In the event of the Contingency determined in the previous paragraph, the sellers will reimburse to YYY an amount in US dollars, in accordance with paragraph 4 below in this letter, if the official exchange rate of the Argentine peso decreases with respect to the US dollar; or YYY will reimburse the sellers that amount if the official exchange rate of the Argentine peso increases with respect to the US dollar.

The beginning of this paragraph exhibits the protasis of a conditional clause, which resumes paragraph 2. ('In the event of the Contingency...'), coupled with an apodosis that reveals the two possibilities presented regarding the contingency, namely, the course of the modification in the peso-dollar parity, which would imply a benefit or harm for the parties, quantified in the following paragraph (4.), which refers to an annex. In paragraph 5, a protasis resumes the content of 3. and 4., and then includes the apodosis to estimate the updated values. The text concludes with the date and the signature of the party representatives, completing the 'framework' with context information about the situation, time reference and persons responsible for the companies, who undertake the contractual commitment.

The letter of agreement, conceived as a tool for the resolution of economic disputes that might result from possible changes in the rate of the peso with respect to the dollar, 
is the main text used to elucidate the confrontation between parties: Did the contingency (desvinculacion of the parity of the Argentine peso and the US dollar) take place before December, 31 st 2001? The selling party, who would receive the financial compensation, considered that had been the case since different government measures imposed during December had restricted and frozen the unlimited currency exchange and, in fact, the price of the peso had depreciated in the actual transactions. The buying party argued that the desvinculacion had not taken place, because the currency devaluation had been determined on January, 9th 2002 by the legislative authorities. The interpretation possibilities, as demonstrated in this article, are deeply related to the events of the extra-linguistic context, but the discursive and linguistic material significantly narrows and restricts them. The following section delves into some of the linguistic resources that the negotiators used to elaborate the letter of agreement, relying on a dominant vagueness strategy which enabled an interpretation in favour of the complaining party.

\subsubsection{Lexical grammatical analysis}

As previously anticipated, linguistic research on the set of texts related to the dispute followed a comprehensive analytical methodology, which included different linguistic levels and was oriented toward disambiguating the interpretive possibilities. By examining the first two paragraphs of the letter and focusing on the lexical and grammatical choices, two opposite yet converging strategies in legal and commercial texts can be distinguished: the first one is the apparent precision in the grammatical structures of condition and in the use of definitions as a resource, aimed at defining the reach of the contingency possibility; but there is also a second one, vagueness, evidenced by the lexical choices and used deliberately to cover a broad range of events that may take place.

1. The signatories agree that the price paid by XXX, in accordance with section number 2 of the Contract, will be subject to revision if the Contingency anticipated in the second paragraph of this letter takes place before December, $31^{\text {st }} 2001$.

2. For the purposes of this letter, Contingency is understood as the desvinculacion of the official exchange rate of the Argentine peso with respect to the US dollar, regardless of the cause that produces it.

Both strategies, purposefully included by the parties, had a compelling reason the highly unpredictable Argentine economic context during the remaining of 2001. Bhatia (2010) suggests distinguishing between 'internal ambiguity' in the text (called 'vagueness' or 'indeterminacy') and 'ambiguity originated in the context' in which the text should be inserted. Fragments 1 and 2 apparently constitute an accurate and consolidated illustration of that twofold ambiguity.

After carefully reading the second sentence, essential for the interpretation, it is possible to notice that its vagueness or indeterminacy stems from the strategic use of 
linguistic resources, namely, the lexical, morphological and grammatical choices. In this section, the type of linguistic analysis performed will be discussed, focusing on the key phrase used to define the contingency: 'the desvinculacion of the official exchange rate of the Argentine peso with respect to the US dollar, regardless of the cause that produces it.'

\subsubsection{Lexicographical analysis}

A crucial stage of the linguistic analysis consisted in the lexicographical study and analysis of the lexical field related to desvinculacion, but it also included the lexical fields related to 'contingency' and 'official exchange rate'. For that purpose, the sources consulted were general and specialised dictionaries. ${ }^{2}$ Due to space limitation and the focus of this study, only the analysis related to desvinculación will be presented. Based on the study of the controversy documents, a list of words that shared a semantic content with desvinculación was established, including: alteración de la paridad cambiaria [fixed exchange rate modification], apreciación (del tipo de cambio) [exchange rate appreciation], aumento [increase], depreciación [depreciation], disminución [decrease], devaluación [devaluation].

The linguistic analysis, following the study of the text material, defined the desvinculacion estimation of the confronting parties as the possibility of 'a peso-dollar fixed exchange rate modification'; in other words, this phrase was considered a synonym equivalent to the desvinculacion of the official exchange rate ${ }^{3}$. Such modification of the fixed exchange rate could, hypothetically, take two courses - the increase or decrease of the rate during the period established. In both cases, the Spanish language has at least two synonymous pairs that vary in register: apreciación [appreciation] and depreciación [depreciation] (economic terminology), and aumento [increase] and disminución [decrease] (more general words). Moreover, the term devaluacion [devaluation] is generally used to refer to the currency value decrease, included both in general and economic dictionaries, but with a distinctive semantic feature: the need for an intervention of a monetary authority in order to trigger it. These are some specialised glossary entries:

[DBT] Devaluación: [...] Reducción del valor de la moneda de un país en relación con las demás monedas realizada por las autoridades monetarias de un país. [Devaluation: (...) Decrease in the currency value of a country with respect to other currencies by the monetary authorities of a country]

[DBV] Devaluación: Operación financiera establecida por mandato de la Autoridad monetaria de un país por la que se procede a dar un menor valor a la moneda nacional frente a las extranjeras lo que implica que desde el momento de la devaluación habrá que pagar más unidades monetarias nacionales para adquirir unidades monetarias exteriores. [Devaluation: Financial operation established by Monetary Authority regulation of a country by which a decreased value can be assigned to the national currency with respect to international currencies, which implies that from the 
moment of the devaluation, one should pay more national monetary units in order to acquire international monetary units]

On the contrary, the word desvinculacion is not included in specialised glossaries; general dictionaries include entries such as the following, which specify its derivation of the verb desvincular [de-link].

[DRAE] desvinculación 1.f. Acción y efecto de desvincular. [de-linking 1. Action and effect of de-linking]

[LEMA] desvinculación n.f. 1 Acción de desvincular. 2. Efecto de desvincular. [delinking (noun) 1. Action of de-linking. 2. Effect of de-linking]

[DEA] desvinculación f Acción de desvincular(se). Tb. su efecto. | Abc 18.3.75, 44:

El padre Diez-Alegría ... ha decidido su desvinculación de la Compañía. [de-linking Action of de-linking (from sth). Also its effect. Abc 3/18/75, 44: Father DiezAlegría ... has determined his de-linking from the Company]

The lexical analysis, based on lexicographical studies, allowed the drawing of the following lexical field, which describes the position of each lexical unit in the semantic structure and reflects the different relations between the lexemes studied (please note that the archilexemes are displayed sintagmatically).

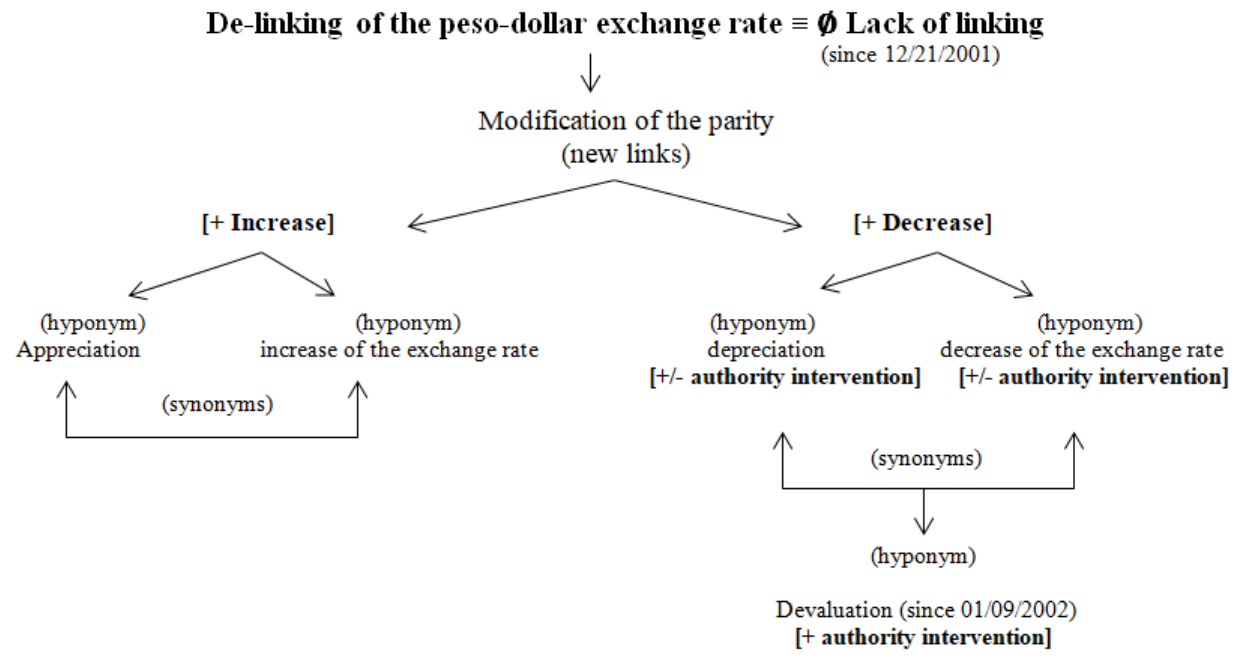

Figure 1. Lexical field analysis.

The lexical analysis served as a sound foundation for the expertise argument: the desvinculacion of the 1-1 ratio between the peso and the dollar, the modification of the fixed exchange rate, had occurred on December, $21^{\text {st }}$ 2001, when the bank holidays were established and the access to the official exchange rate was cancelled. On that moment, the Argentine currency depreciation began, an extra linguistic fact that constitutes the context that captures the general word desvinculacion. Devaluation, however, took place 
due to the decree enacted on January, 9th 2002 on the basis of the repealed law. The lexical vagueness carried in the wording of the section adds to other linguistic aspects: on the one side, the lexical meaning and noun morphology and, on the other side, the key verbal phrase syntax.

\subsubsection{Morphosyntactic analysis}

From the morphological point of view, the key word desvinculacion is a nominalisation, that is to say, it derives from a verbal stem (desvincular), and it allows two interpretations: an eventive and a resultative one, which can become explicit from the morphological analysis of all its components, particularly its affixes (Bosque, 2016; García-Medall, 2019). First, the Spanish prefix des- (similar to the English prefixes 'dis-', 'de-' or 'un') should be considered. This prefix is included within the negative category, because it negates the semantic characteristics of the content in the stem to which it is added. It may have different meanings: 'reversion' and 'lack of' or 'deficit'; each of these meanings is associated with two different morphological structures (Varela \& Martín García, 1999).

At this point, it is convenient to examine the meaning of 'reversion', which refers to the possibility of returning to a previous state. For instance, it is found in the verb deshacer [undo], which denotes the reversal of an action, because that action leads to the previous state of hacer [do]. The same happens with the verbs aparecer/desaparecer [appear/disappear], organizar/desorganizar [organise/disorganise], poblar/despoblar [populate/depopulate]). The prefix des- with the contrary meaning is linked to verbal stems of perfective aspect; ${ }^{4}$ thus, according to this interpretation, to work with the word desvinculacion it is necessary to present the following morphological structure that enables the meaning of 'action or effect of desvincular':

Vínculo $>$ vincular $>$ desvincular $>$ desvinculación: $=$ "acción y efecto de desvincular [action and effect of de-linking]"

$\left[\left[\text { Des }\left[\left[\text { vincul }_{\mathrm{N}}\right] \mathrm{a}_{\mathrm{v}}\right]_{\mathrm{v}}\right] \text { ción }\right]_{\mathrm{N}}$

Conversely, the prefix des- with the meaning 'deprivation' denotes the lack of what is intended in the stem and is added to nominal stems to indicate the lack of the entity denoted in the simple noun (desorden; desacuerdo) [disorder; disagreement]. ${ }^{5}$ With this meaning, there arises a morphological interpretation different from the previous one, presented below:

Vínculo $>$ vincular $>$ vinculación $>$ desvinculación $=$ "falta $/$ carencia de vinculación [lack of/deficit of linking]"

$\left[\operatorname{Des}\left[\left[\left[\text { vincul }_{\mathrm{N}}\right] \mathrm{a} \text { v]ción }\right]_{\mathrm{N}}\right]_{\mathrm{N}}\right.$

Secondly, the affix that concludes the nominalisation is the Spanish suffix -cion (similar to the English prefix '-tion'), which has the function of generating nouns from 
verbs (pesificar $>$ pesificación) [pesify $>$ pesification]. The nominalisations created this way, such as desvinculacion, tend to be ambiguous from the point of view of their meaning: they can refer to an event (a process or an action, that is to say, something that occurs in a period of time) or they can denote an object, a state, a characteristic or a product that results from an event or process. In other words, they bear two meanings: eventive (dynamic) and resultative (static). Consequently, in the following sentences, pesificación and dolarización have two possible interpretations, which can be disambiguated if particular modifiers are included. In order to favour the eventive or process interpretation, a predicate conveying the period of time could be added:

(a)

La pesificación de los depósitos ocurrió durante el año 2002

[The pesification of bank deposits occurred during 2002]

La dolarización de la economía duró varios años

[The dollarisation of the economy lasted several years]

In order to favour the strictly resultative (static) interpretation, produced when the events or processes of pesificar or dolarizar generate an effect or result, it is possible to add expressions to clarify or present characteristics:

(b)

La pesificación de los depósitos fue una calamidad

[The pesification of bank deposits was a tragedy]

La dolarización de la economía es inconsistente

[The dollarisation of the economy is inconsistent]

The main conclusion is that nominalisations such as desvinculación can be ambiguous and the specific syntactic context can favour the eventive or resultative interpretation. Therefore, to disambiguate the interpretation it was necessary to argue about different aspects: the amount of arguments in the nominalisation (see below) and, particularly, the role of the operator ('regardless of the cause that produces it').

The meanings of the verb vincular [linking] depict the general meaning of 'relation' or 'union', which derives from vinculo [link] and reveal the possibilities of syntactic and argumentative combination (Picallo, 1999). The verb with the negative prefix, desvincular, preserves those combination possibilities. The meanings found in dictionaries open the path towards the interpretation that the verb desvincular and its nominal derivation desvinculación require three entities to generate a sentence:

Algo/Alguien entidad 1 (des)vincula una cosa entidad 2 de otra entidad 3

[Something/Someone entity 1 (de-)links one thing entity $2_{\text {from another }}$ entity 3]

The three entities required by the verb or the nominal derivation can be presented in the syntax following two schemes, with two or three arguments: 
a. With two arguments, when the second one necessarily denotes a plural entity: desvincular v.tr. Deshacer <una persona o una cosa> el vínculo entre [personas o cosas]: Ejemplo: El destino [A1] desvinculó sus vidas [A2] [de-linking tr.v. Breaking $<$ a person or a thing $>$ the connection between [persons or things]. Example: Destiny [A1] de-linked their lives[A2]]

b. With three arguments: desvincular tr.v. 1 Acabar con la vinculación que existe entre varias personas o cosas: Ejemplo: el juez ${ }_{[A 1]}$ que instruye el caso desvinculó a la mujer [A2] de cualquier implicación en el asesinato[A3] [LEMA] [de-linking tr.v. 1 Putting an end to the link that exists between several people or things. Example: the judge ${ }_{[A 1]}$ in charge of the case delinked the $\operatorname{woman}_{[\mathrm{A} 2]}$ from being implicated in the $\left.\operatorname{murder}_{[\mathrm{A} 3]}\right]$

The linguistic expertise involved the following question: Which is the accurate interpretation of desvinculacion, included in the letter of agreement? That is to say, which are the arguments (and how many are there) related to the word and which are the thematic roles of these arguments included within the phrase? The grammatical analysis allowed the reader to identify syntactic relations of different hierarchy and order:

[la desvinculación [del tipo de cambio oficial del peso argentino con el dólar USA] $\left.{ }^{1.1 .}\right]^{1}$ [cualquiera que sea la causa que la produzca]2] SV

[the desvinculacion [of the official exchange rate of the Argentine peso with respect to the US dollar $\left.{ }^{1.1}\right]^{1}$ [regardless of the cause that produces it]2] VP

Syntactic interpretation allowed a well-grounded observation of a division into two components: 1['the desvinculación of the official exchange rate of the Argentine peso with respect to the US dollar'] and 2['regardless of the cause that produces it']. This demonstrates that the relation of the causal operator 2 ['regardless of the cause that produces it'] is established with the whole previous component; in other words, it is an operator that restricts the complete previous segment. Likewise, it is possible to determine other internal structural layers in component 1 :

[ [la desvinculación [d [el tipo de cambio oficial [del peso argentino 1.3.] [con el dólar USA 1.4. $\left.\left.\left.{ }^{1.2}\right]^{1.1}\right]^{1}\right]$ [cualquiera sea la causa que la produzca $\left.]^{2}\right] \mathrm{SV}$

[[the desvinculacion [of[the official exchange rate [of the Argentine peso 1.3.] [with respect to the US dollar 1.4. $\left.\left.{ }^{1.2}\right]^{1.1}\right]^{1}$ ] [regardless of the cause that produces it $]^{2}$ VP

In summary, the morphosyntactic analysis enabled the conclusion that the phrase is articulated on the basis of its deverbal nucleus, desvinculacion, which organises two simultaneous structural levels expressing different relations. On the one hand, there is a more global level that denotes the sense of desvinculacion with two arguments. Operator 2['regardless of the cause that produces it'] functions as the operator ${ }_{[1]}$ of desvinculacion, undertaking the semantic role of cause; and the constituent "the official exchange rate of the Argentine peso with respect to the US dollar" marked with 1.1 is the $\operatorname{argument}_{[2]}$ that undertakes the semantic role of 'theme'. A possible paraphrase of 
the structure is: 'any cause' can produce 'the desvinculacion of the official exchange rate of the Argentine peso with respect to the US dollar'.

By doing this, it was possible to demonstrate the central role of the operator in the interpretation of desvinculacion involving two components (the most external structural level): 'one thing de-links another thing' —-some cause [A1] de-links the exchange rate [A2]. From the linguistic point of view, it can be asserted that the syntacticmorphological structure of the phrase favours the broad interpretation of desvinculacion and blocks any other type of interpretation restricted in order for the contingency to occur.

Furthermore, the meaning of the causal operator ['regardless of the cause that produces it'] invalidates the reduced interpretation of desvinculacion, as its meaning precisely functions the other way around. On the one hand, it is necessary to highlight the use of the Spanish indefinite pronoun cualquiera, that has been explained by several authors as an 'indifference pronoun'. On the other hand, the choice of the subjunctive verbal mode (although characterized by that pronoun) in all the Spanish verbs within the operator (sea, produrca) should be noted, which is clearly the required mode to express states and events that imply some kind of doubt, uncertainty, indeterminacy.

All things considered, the linguistic analysis provides strong arguments in favour of one of the interpretations of the letter of agreement, which indicated that the fixed exchange rate had occurred before the period established (12/31/2001). Namely, this was the interpretation that enabled all the possible causes of currency modification within the period established (and that opposed a limited interpretation, in the sense of an official devaluation, defined by the buying party). Such interpretation is not a sophisticated understanding; it is probably the most natural interpretation offered by the letter of agreement. However, in the case of contractual disputes occurring in factual contexts of legal and economic ambiguity, the textual material — conceived to guide the way to proceed in (hard-to-predict) future events and therefore, carrying a considerable attribute of indeterminacy - may be subject to divergent interpretations once the events take place. Linguistic arguments, added to economic and legal ones, supported the convenient interpretation for the buying party.

\section{CONCLUSIONS}

This article has provided descriptive knowledge about a prospective genre of professional communication: the letter of agreement, a genre that, given its superstructure scheme (frame of reference, mention of the interacting parties, brief formulation, deal with signatures) and due to its own name 'letter of agreement', is included in the family of commercial epistolary genres. However, it is evident that it has a strong kinship relationship with commercial contracts or agreements, which usually constitute binding texts for the parties, since it limits and specifies relevant details of the transaction or operation carried out. From the functional point of view, it is a 
directive-commissive text: the signing parties assume a commitment to comply with the conditions agreed on. It specifically determines interpretation conditions anticipating future or hypothetical events or situations that may affect the signing parties. For this reason, this genre usually includes different features and resources that simultaneously convey an inaccuracy and accuracy intention (general words, terminology, process and result nominalisations, hypothetical structures, indeterminacy operators, etc.), which must be interpreted through the use of linguistic analysis tools. As a result of the analysis carried out, the interpretation of prospective texts such as agreement letters is improved if performed together with a comprehensive linguistic analysis, considering the different dimensions of texts: lexical-grammatical and textual-discursive. The descriptive results regarding the letter of agreement genre are very preliminary, since only one textual example has been studied in depth, due to the general framework demanded by the research, whose aims were to deepen its interpretative possibilities. The work can be considered an initial step for broader genre studies.

Likewise, this study presents an overall picture of the linguistic expertise process initiated by the introduction of an international legal case that required the specialised expertise of different professionals and was solved by an international court. Even though this study only presents part of the linguistic evidence gathered, it has demonstrated that the tools for textual and linguistic analysis can help disambiguate the interpretation. Moreover, it has confirmed Weinrich's explanation (1995) that the research on specialised texts requires a double effort from linguists: to compromise their own specific knowledge about the discipline and to acquire specific knowledge about the particular professional field.

In fact, it could be argued that the empirical base of this article is restricted, because it is limited to a linguistic expertise case. However, apart from the fact that its resolution required the revision and analysis of a great amount of texts, the main issue relies on Hermeneutics, and its specific reach is the individual text (or its individual meaning "which the author has associated with a text and / or which the text has for the recipient", Adamzik 2004: 15), as expected in that tradition. Naturally, it would be convenient to extend this research to other professional corpuses and relevant genres that entail a controversial dimension (such as verdicts, court objections, appellate procedures, among others), a field quite unexplored at least in the Spanish language.

\section{REFERENCES}

Adamzik, K. (2004). Textlinguistik. Eine einführende Darstellung. Tübingen: Niemeyer.

Adamzik, K. (2016). Textlinguistik. Grundlagen, Kontroversen, Perspektiven. Berlin: De Gruyter. 
Antos, G. (1997). Texte als Konstitutionsformen von Wissen. In G. Antos (Ed.), Die Zukunft der Textlinguistik: Traditionen, Transformationen, Trends (pp. 43-63). Tübingen: Niemeyer.

Barrenechea, A. M. (1990). La epístola y su naturaleza genérica. Dispositio, 15(39), 51-65.

Beaugrande de, R. \& Dressler, W. (1997). Introducción a la lingüística del texto. Madrid: Ariel.

Bergmann, J. \& Luckmann, Th. (1995). Reconstructive genres of everyday communication. In U. Quasthoff (Ed.), Aspects of Oral Communication (pp. 289304). Berlin: de Gruyter.

Bhatia, V. (2010). Legal writing: Specificity. In M. Coulthard \& A. Johnson (Eds.), The Routledge Handbook of forensic Linguistics (pp. 37-50). Oxon: Routledge.

Bhatia, V. (2015). Critical genre analysis: Theoretical preliminaries. Hermes, 54, 9-20.

Bosque, I. (2016). Sustantivo. In J. Gutiérrez-Rexach (Ed.), Enciclopedia de lingüística bispánica (pp. 11-123). Oxon: Routledge.

Bouvet, N. (2006). La escritura epistolar. Buenos Aires: Eudeba. Enciclopedia Semiológica.

Cabré, T. (1999). La terminología. Representación y comunicación. Una teoría de base comunicativa y otros artículos. Barcelona: Institut Universitari de Lingüística Aplicada, Universitat Pompeu Fabra. (Serie Monografies, 3).

Ciapuscio, G. (2003). Textos especializados y terminología. Barcelona: Publicaciones del Institut Universitari de Lingüística Aplicada (IULA) Universitat Pompeu Fabra. Sèrie Monografies, Nro. 6.

Ciapuscio, G. (2016). Textes et discours scientifiques. En W. Forner \& B. Thörle (Eds.), Manuel des langues de spécialité (pp. 121-146). Berlin: de Gruyter.

Ciapuscio, G. (2021). Géneros textuales y tipos de discurso. En Ó. Loureda \& A. Schrott (Eds.), Manual de lingüistica del hablar (pp. 541-558). Berlin, Boston: de Gruyter.

Ciapuscio, G. \& López Ferrero, C. (2021). El estudio del discurso especializado basado en corpus: el caso de las cartas. En G. Parodi, P. Cantos \& Ch. Howe (Eds.), The Routledge Handbook of Spanish Corpus Linguistics (en prensa).

Ciapuscio, G., Adelstein, A. \& Gallardo, S. (2010). El texto especializado: Propuesta teórica y prácticas de capacitación académica y profesional en Argentina. En G. Parodi (Ed.), Alfabetización académica y profesional en el siglo XXI: Leer y escribir desde las disciplinas (pp. 317-346). Santiago: Ariel.

Copi, I. (1972). Introducción a la lógica. Buenos Aires: EUDEBA. 
Coulthard, M. (2005). Algunas aplicaciones forenses de la lingüística descriptiva. In M. T. Turell (Ed.), Lingïistica forense, lengua y derecho. Conceptos, métodos y aplicaciones (pp. 249-274). Barcelona: Institut Universitari de Lingüística Apicada.

da Cunha, I. \& Montané, A. (2020). A corpus-based analysis of textual genres in the administration domain. Discourse Studies, 22(I), 3-31.

Díaz, L. \& Lucha, R. M. (2018). Las cartas de solicitud de trabajo en ELE y la tradición discursiva en L1 y L2. A propósito de los textos conversacionales y sus géneros en el aula de ELE. Marco ELE, 26, 1-41.

García-Medall, J. (2019). La morfología derivativa del español. In E. Ridruejo (Ed.), Manual de Lingüistica Española (pp. 402-430). Berlin: de Gruyter.

Göpferisch, S. (2000). Analysing LSP Genres (Text Types): From Perpetuation to Optimization in Text (-type) Linguistics. In A. Trosborg (Ed.), Analysing Professional Genres (pp. 227-247). Amsterdam/Philadelphia: John Benjamins.

Gotti, M. (2008). The formulation of legal concepts in arbitration normative texts in a multilingual, multicultural context. In V. K. Bhatia, Ch. Candlin \& P. Evangelisti Allori (Eds.), Language, Culture and the Law. The Formulation of Legal Concepts across Languages and Cultures (pp. 23-45). Linguistic Insights Series. Bern: Peter Lang.

Heinemann, W. (2000). Textsorten. Zur Diskussion um Basisklassen des Kommunizierens. Rückschau und Ausblick. In K. Adamzik (Ed.), Textsorten. Reflexionen und Analysen (pp. 9-29). Tübingen: Stauffenburg.

Heinemann M. \& Heinemann, W. (2002). Grundlagen der Textlinguistik. Tübingen: Max Niemeyer Verlag.

Montolío, E. (2010a). Mejorar las recomendaciones contenidas en los informes elaborados por consultores. La optimización del discurso. Onomázęin, 21, 237253.

Montolío, E. (2010b). Discourse, grammar and professional discourse analysis: The function of conditional structures in legal writing. In D. Simone Giannoni \& C. Frade (Eds.), Researching Language and the Law (pp. 19-45). Bern: Peter Lang AG.

Orts, M. Á. (2015). Power and complexity in legal genres: Unveiling insurance policies and arbitration rules. International Journal for the Semiotics of Law, 28(3), 485-502.

Parodi, G. (Ed.) (2005). Discurso especializado e Instituciones Formadoras. Valparaíso: Ediciones Universitarias de Valparaíso. 
Pastor Villalba, C. (2011). Estudio transcultural del discurso argumentativo: La queja escrita en español y alemán. Tesis doctoral, Universitat Pompeu Fabra, Barcelona, España [on line]. Retrieved from: https://repositori.upf.edu/handle/10230/13093?locale-attribute=es

Picallo, M. C. (1999). La estructura del sintagma nominal: Las nominalizaciones y otros sustantivos con complementos argumentales. In I. Bosque \& V. Demonte (Dirs.) Gramática descriptiva del español (pp. 363-393). Madrid: Espasa Calpe.

Ruiz Moneva, M. Á. (2013). Cognition and context of legal texts: Spanish and English judgments compared. Revista de lingüistica y lenguas aplicadas, 8, 76-92

Sandig, B. (2000). Text als prototypisches Konzept. In M. Mangasser-Wahl (Ed.), Prototypentheorie in der Linguistik (pp. 93-112). Tübingen: Stauffenburg.

Schröder, H. (Ed.) (1991). Subject-oriented Texts. Languages for Special Purposes and Text Theory. Berlin/New York: de Gruyter.

Varela, S. \& Martín García, J. (1999). La prefijación. In I. Bosque \& V. Demonte (Dirs.) Gramática descriptiva del español (pp. 4993-5038). Madrid: Espasa Calpe.

Weinrich, H. (1995). Wissenschaftssprache, Sprachkultur und die Einheit der Wissenschaft. In H. Weinrich \& H. Kretzenbacher (Eds.), Linguistik der Wissenschaftssprache (pp. 155-174). Berlin/New York: de Gruyter.

\section{ACKNOWLEDGEMENTS}

My gratitude to Andreína Adelstein, for her contributions during the expertise stage, to Laura Ferrari and Nina Gerassi-Navarro for her observations on this paper. I am solely responsible for any possible mistakes.

\section{NOTES}

${ }^{1}$ In order to preserve the confidentiality of the content, all the individual references have been deleted from the document.

2 The lexicographical analysis was based on several dictionaries, both general and specialised. Here are some of the main works consulted. General dictionaries: Real Academia Española. Diccionario de la lengua española, 23. ${ }^{a}$ ed., [DRAE Version 23.3, on line]. <https://dle.rae.es>; Seco, Manuel et al. (1999). Diccionario del español actual [DEA]. Madrid: Aguilar; Universidad de Salamanca (1996). Diccionario Salamanca de la lengua Española. Madrid/Salamanca: Editorial Santillana; Battaner Arias, Paz (2001). LEMA. Diccionario de la lengua española (VOX). Barcelona: Spes Editorial; Specialised dictionaries: Reuters (2001). Diccionario de Finanqas. Nueva Jersey: Prentice Hall; Bolsa de Valencia. Diccionario de la bolsa de Valencia. [on line 
version] $<$ http://www.bolsavalencia.es/Diccionario/>;

http://teleline.terra.es/personal/rebolsa/dicibolsa.htm; Currency exchange glossary. [on line

version] <http://www.expansiondirecto.com/inversion/glosario/divisas.html>; Financial terminology glossary. [on line version] $<$ http://www.bmv.com.mx/BMV/HTML/sec1 glosario.html $>$; Specialised dictionaries in English: http://www4.tiaa-cref.org/libra/dictionary/Financial; The Economist. Business encyclopedia. [on line version] <http://www.economist.com/encyclopedia/>; Financial dictionary. [on line version] $<$ http://www.investopedia.com/dictionary/ $>$.

${ }^{3}$ This equivalence was accepted by both confronting parties as well as the legal and economic experts.

${ }^{4}$ That is to say, these are complex verbs that convey the previous action or state denoted by the stem, as in deshacer, desvestir [undo, undress]. In order to establish the opposition between both actions (do v. undo) it is necessary for the non-contrary action indicated in the stem to be finished and denote a perfective process, on which the contrary prefix (des-) will function to cancel it and return it to the previous state (Varela \& Martín García, 1999: 5029).

${ }^{5}$ These nominal stems are also derived, by substraction, from verbs: ordenar $<$ orden $<$ desorden. 